IBIMA Publishing

Journal of Enterprise Resource Planning Studies http://www.ibimapublishing.com/journals/JERPS/jerps.html

Vol. 2013 (2013), Article ID 227873, 13 pages

DOI: $10.5171 / 2013.227873$

Research Article

\title{
Factors Affecting ERP Implementations: Client and Consultant Perspectives
}

\author{
Uchitha Jayawickrama $^{1}$ and Saman Yapa ${ }^{2}$ \\ ${ }^{1}$ School of Management, Plymouth University, Plymouth, United Kingdom \\ ${ }^{2}$ University of Sri Jayewardenepura, Nugegoda, Sri Lanka
}

Received 17 July 2012; Accepted 6 October 2012; Published 27 February 2013

Academic Editor: Sandro Geric

\begin{abstract}
Enterprise Resource Planning (ERP) systems are becoming popular among business organizations globally as well as locally. The main reason is that the corporate benefits gained through such implementations. However, in the event of such a project failing, the company has to incur a huge loss. Therefore, identifying the issues involved with the ERP implementation is of paramount importance. This paper aims to identify factors affecting the successful implementation of ERP projects, find out the level of practice of each factor in Sri Lankan organizations and recommend best practices to minimize the ERP project failures. The findings of this research are based on a questionnaire survey performed among 31 client organizations and 32 ERP consultants selected through judgmental sampling method. There are 3 factors each for client and consultant perspectives where the level of practice is poor, they are; product selection procedure, project planning, client commitment, competency of consultants and communication of support requirements during the pre-implementation stage. Except for above, level of practice of rest of the factors is good. Set of guidelines has been suggested to overcome the poorly practiced implementation factors in order to follow in future ERP implementations for both clients and consultants.
\end{abstract}

Keywords: ERP implementation, Success factors, Client perspective, Consultant perspective.

\section{Introduction}

An Enterprise Resource Planning (ERP) system is an integrated software solution, typically offered by a vendor as a package that supports the seamless integration of all the information flowing through a company, such as financial, accounting, human resources, supply chain and customer information (Davenport, 1998). Gunasegaram (2007) defines the key elements of an ERP system as: one large real-time database which reduces data redundancy and improves accuracy; integrated business process that cut across business functions such as supply chain management; and seamless transitions between business transactions.

In response to the growing global competition, many companies all over the world have embarked upon ERP

Copyright (C) 2013 Uchitha Jayawickrama and Saman Yapa. This is an open access article distributed under the Creative Commons Attribution License unported 3.0, which permits unrestricted use, distribution, and reproduction in any medium, provided that original work is properly cited. Contact author: Uchitha Jayawickrama E-mail: uchitha.jayawickrama@plymouth.ac.uk

How to Cite this Article: Uchitha Jayawickrama and Saman Yapa, "Factors Affecting ERP Implementations: Client and Consultant Perspectives," Journal of Enterprise Resource Planning Studies, vol. 2013, Article ID 227873, 13 pages

DOI: $10.5171 / 2013.227873$ 
implementation. The ERP system market is one of the fastest growing markets in the software industry (Willis and Willis-Brown, 2002). Current major ERP vendors are SAP and Oracle; these two vendors occupy $42 \%$ and $25 \%$ of the market respectively (AMR Research, 2007). MS Dynamics has a market share of $7 \%$ while IFS has only $1 \%$ from the ERP market (AMR Research, 2007). Many researches have described that there is a noticeable difference between ERP projects and software projects (Bingi et al., 1999; Majed, 2003). Most software projects are focused on developing a standalone software system. But an ERP project is composed of software projects as well as business processes.

Nowadays, ERP systems are becoming a trend in Sri Lanka as well. Organizations in Sri Lanka tend to invest heavily on ERP systems seeking for the benefits promised to gain corporate excellence.

In general, ERP systems, if implemented properly, provide enormous benefits to organizations. However, not all ERP implementations deliver the promised enterprise improvements. There are many situations where ERP implementation has become a failure. There have been many difficult and costly implementations of ERP systems that have adversely affected many organizations. According to Gunasegaram (2007) the companies that have failed in ERP implementations include FoxMeyer Drug, Dell Computer, Applied Materials and Dow Chemical. According to the evaluation of Standish Group International, $90 \%$ of SAP R/3 projects run late (Scott and Vessey, 2002) and Williamson (1997) signified that $3 / 4$ of ERP projects were considered as failures and unacceptable. In the case of FoxMeyer Drug, the project has led the company to a bankruptcy proceeding (Scott and Vessey, 2002). There may be lots of factors that might affect the success of ERP implementation.

Even though many researches have been carried out in other countries, hardly any research in this nature has been done in Sri Lanka.

The objectives of this research are to identify significant factors that have an impact on ERP implementations, to find out the perception of the client and consultants on application of these factors and to recommend a set of guidelines to overcome the poorly practiced implementation factors in order to avoid failures in future ERP implementations. 


\section{Literature Review}

\section{Table 1.1: Factors Affecting ERP Implementations - As Identified by Different Researchers}

\begin{tabular}{|c|c|}
\hline Researcher & Factors affecting ERP implementations \\
\hline $\begin{array}{l}\text { Somers and } \\
\text { Nelson }(2001)\end{array}$ & $\begin{array}{l}\text { Top management support, Project team competence, Interdepartmental co-operation, Clear } \\
\text { goals and objectives, Project management, Inter-departmental communication, Management } \\
\text { of expectations, Project champion, Vendor support, Careful package selection, Data analysis } \\
\text { and conversion, Dedicated resources, Steering committee, User training, Education on new } \\
\text { business processes, Business Process Reengineering (BPR), Minimal customization, } \\
\text { Architecture choices, Change management, Vendor partnership, Vendor tools, Use of } \\
\text { consultants. }\end{array}$ \\
\hline $\begin{array}{l}\text { Nah et al. } \\
(2001)\end{array}$ & $\begin{array}{l}\text { ERP teamwork and composition, Top management support, Business plan and vision, } \\
\text { Effective communication, Project management, Project champion, Appropriate business and } \\
\text { legacy systems, Change management program and culture, Business Process Reengineering } \\
\text { (BPR) and minimum customization, Software development, testing and troubleshooting, } \\
\text { Monitoring and evaluation of performance. }\end{array}$ \\
\hline $\begin{array}{l}\text { Huang et al. } \\
(2004)\end{array}$ & $\begin{array}{l}\text { Lack of senior manager commitment to project, Ineffective communications with users, } \\
\text { Insufficient training of end-user, Fail to get user support, Lack of effective project } \\
\text { management methodology, Attempting to build bridges to legacy applications, Conflicts } \\
\text { between user departments, The composition of project team member, Fail to redesign } \\
\text { business process, Unclear/Misunderstanding changing requirements. }\end{array}$ \\
\hline $\begin{array}{l}\text { Wong et al. } \\
(2005)\end{array}$ & $\begin{array}{l}\text { ERP system misfit, High turnover rate of project team members, Over-reliance on heavy } \\
\text { customization, Poor consultant effectiveness, Poor IT infrastructure, Poor knowledge } \\
\text { transfer, Poor project management effectiveness, Poor quality of Business Process } \\
\text { Reengineering (BPR), Poor quality of testing, Poor top management support, Too tight } \\
\text { project schedule, Unclear concept of the nature and use of ERP system from the users' } \\
\text { perspective, Unrealistic expectations from top management concerning the ERP System, } \\
\text { Users' resistance to change. }\end{array}$ \\
\hline $\begin{array}{l}\text { Upadhyay et } \\
\text { al. (2011) }\end{array}$ & $\begin{array}{l}\text { Top management support, Project team competence, Project management, User training and } \\
\text { education, External consultants, Proper package selection, Vendor's staff knowledge and } \\
\text { support, Clear goals and objectives, User involvement and participation, Project champion, } \\
\text { Project cost, Effective change management, Project composition and leadership, } \\
\text { Organizational communication, Information flow management, Minimum customization. }\end{array}$ \\
\hline $\begin{array}{l}\text { Significant } \\
\text { Implementa }\end{array}$ & 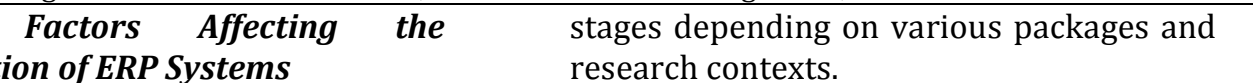 \\
\hline
\end{tabular}

A number of researches have been carried out in different countries to identify critical success factors of an ERP implementation. Table 1.1 summarises the factors identified by different researchers.

From Table 1.1 it is clear that different authors have identified different factors in different contexts. However, it is important to note that all the researchers have identified the top management commitment as one of the important factors.

\section{ERP Implementation Stages}

Researchers (Ehie and Madsen, 2005; Yu, 2005; Gunasekaran, 2007) have divided ERP implementation process in to different
According to $\mathrm{Yu}$ (2005) there are three main stages in an ERP implementation; i.e. pre-implementation, implementation (also known as during implementation) and post-implementation. Further these stages can be divided in to sub stages for various purposes such as ease of planning, execution, etc.

Three stage methodology proposed by $\mathrm{Yu}$ (2005) was adopted in the present research after discussions with many domain experts in Sri Lanka.

\section{Methodology}

Nine factors, identified through the literature, were selected that are most relevant to the Sri Lankan context through 
a pilot study carried out among domain experts in Sri Lanka. Those nine factors have been categorized under three main stages of the ERP implementation i.e. preimplementation, implementation and postimplementation.

Table 2.1: Identified Factors and the Supported Literature

\begin{tabular}{|c|c|c|}
\hline No & Factor & Literature \\
\hline \multicolumn{3}{|c|}{ Pre-implementation } \\
\hline 1 & $\begin{array}{l}\text { Product } \\
\text { procedure. }\end{array}$ & $\begin{array}{l}\text { Upadhyay et al. (2011), Huang et al. (2004), Wong et al. (2005), } \\
\text { Somers and Nelson (2001), Nah et al. (2001) }\end{array}$ \\
\hline 2 & $\begin{array}{l}\text { Understanding } \\
\text { justification of and } \\
\text { business need of } \\
\text { implementing the ERP } \\
\text { system in the organization. }\end{array}$ & $\begin{array}{l}\text { Upadhyay et al. (2011), Huang et al. (2004), Somers and Nelson } \\
\text { (2001), Nah et al. (2001), Wong et al. (2005) }\end{array}$ \\
\hline \multicolumn{3}{|c|}{ Implementation } \\
\hline 3 & Project Planning. & $\begin{array}{l}\text { Upadhyay et al. (2011), Huang et al. (2004), Wong et al. (2005), } \\
\text { Somers and Nelson (2001), Hellens et al. (2005), Nah et al. } \\
\text { (2001), Kim et al. (2005) }\end{array}$ \\
\hline 4 & Client commitment. & $\begin{array}{l}\text { Upadhyay et al. (2011), Huang et al. (2004), Wong et al. (2005), } \\
\text { Somers and Nelson (2001), Rao (2000) }\end{array}$ \\
\hline 5 & $\begin{array}{l}\text { Competency of } \\
\text { consultants. }\end{array}$ & $\begin{array}{l}\text { Upadhyay et al. (2011), Wong et al. (2005), Somers and Nelson } \\
\text { (2001), Huang et al. (2004), Hellens et al. (2005) }\end{array}$ \\
\hline 6 & $\begin{array}{l}\text { Commitment from the top } \\
\text { management. }\end{array}$ & $\begin{array}{l}\text { Upadhyay et al. (2011), Huang and Palvia (2001), Huang et al. } \\
\text { (2004), Wong et al. (2005), Somers and Nelson (2001), Hellens et } \\
\text { al. (2005), Nah et al. (2001), Rao (2000), Kim et al. (2005) }\end{array}$ \\
\hline 7 & $\begin{array}{l}\text { Importance given to IT } \\
\text { function within the } \\
\text { organization. }\end{array}$ & $\begin{array}{l}\text { Huang et al. (2004), Light et al. (2001), Rao (2000), Wong et al. } \\
\text { (2005), Hellens et al. (2005), Huang and Palvia (2001) }\end{array}$ \\
\hline \multicolumn{3}{|c|}{ Post-implementation } \\
\hline 8 & $\begin{array}{l}\text { Communication of support } \\
\text { requirements during the } \\
\text { pre-implementation stage. }\end{array}$ & Domain experts view \\
\hline 9 & $\begin{array}{l}\text { Transfer of system } \\
\text { knowledge to the client. }\end{array}$ & $\begin{array}{l}\text { Upadhyay et al. (2011), Huang et al. (2004), Wong et al. (2005), } \\
\text { Somers and Nelson (2001), Hellens et al. (2005), Rao (2000) }\end{array}$ \\
\hline
\end{tabular}

\section{Hypothesis Development}

As the objective of the research was to obtain the views of the consultants and the clients, appropriate hypotheses or testable statements were formulated for each identified factor. For example, the hypotheses developed for factor 1 are as follows;

$\mathbf{H}_{\mathbf{0}}$ 1: Product selection procedure is poor.

$\mathbf{H}_{\mathbf{a}} \mathbf{1}$ : Product selection procedure is good.

Likewise nine hypotheses were developed to test the perception of clients and consultants on the nine selected factors.

\section{Population and Sample}

The population of the research was all the organizations in different industries that have implemented SAP, Oracle, IFS and MS Dynamics ERP systems in Sri Lanka. However, there is no formal directory available to obtain ERP implemented organizations in Sri Lanka. Hence, it is impossible to identify all the elements of the population. In addition, most of the companies that have implemented above four products are quite large entities. Therefore, it is quite difficult to represent all large organizations which are in the population. As such, research sample was selected to represent above mentioned 
famous four products in the Sri Lankan ERP market through judgmental sampling.

Data were gathered by using a questionnaire survey and then they were analyzed by using SPSS in order to find the perceptions of the clients and consultants.

Data were mainly collected from clients and consultants separately through two types of questionnaires prepared based on Likert scale. Questionnaires were tested and validated as a pilot study by obtaining feedback from 8 domain experts and 5 academics prior to using them for actual data collection. After the pilot study, several questions were slightly refined and re-structured in order to ensure the reliability and validity of the questionnaires.

\section{Analysis and Interpretation}

In measuring the perception of clients, only one response was considered from a particular organization i.e. the unit of analysis was the organization.

Each response received by an ERP implementation consultant represented the overall idea about all implementations which s/he involved during his/her career i.e. the unit of analysis was the consultant. Hence, their response did not reflect one particular implementation that consultant involved and experienced.

Since this research has involved hypothesis testing based on quantitative data, deductive approach was used as the research approach.

\section{Presentation and Analysis of Data}

This section discusses the composition and nature of the data gathered for the research study as well as the data analysis performed based on client and consultant responses.

The client questionnaire was distributed among 42 organizations. However, only 31 responses were considered for the analysis since 11 responses were incomplete. Out of 31 responses $39 \%$ represents Oracle implemented companies and 23\% represents SAP implemented companies as shown in Table 3.1. IFS and MS Dynamics were equally represented in the sample with $19 \%$ each. Therefore, it shows that the sample fairly represents each ERP package.

Table 3.1: ERP Package Representation by Client

\begin{tabular}{|l|l|l|l|}
\hline No. & ERP product & $\begin{array}{l}\text { No. of } \\
\text { responses }\end{array}$ & Percentage \\
\hline 1 & SAP & 7 & $23 \%$ \\
\hline 2 & Oracle & 12 & $39 \%$ \\
\hline 3 & IFS & 6 & $19 \%$ \\
\hline 4 & MS Dynamics & 6 & $19 \%$ \\
\hline & & $\mathbf{3 1}$ & $\mathbf{1 0 0 \%}$ \\
\hline
\end{tabular}


Table 3.2: Industry Representation

\begin{tabular}{|l|l|l|l|}
\hline No. & Industry & No. of responses & Percentage \\
\hline 1 & Automobile & 2 & $7 \%$ \\
\hline 2 & Banking & 4 & $13 \%$ \\
\hline 3 & Conglomorate & 4 & $13 \%$ \\
\hline 4 & Food \& Beverage & 3 & $10 \%$ \\
\hline 5 & Garment & 6 & $19 \%$ \\
\hline 6 & Insurance & 2 & $6 \%$ \\
\hline 7 & Manufacturing & 4 & $13 \%$ \\
\hline 8 & Plantation & 1 & $3 \%$ \\
\hline 9 & Telecommunication & 2 & $6 \%$ \\
\hline 10 & Transportation & 3 & $10 \%$ \\
\hline & & $\mathbf{3 1}$ & $\mathbf{1 0 0 \%}$ \\
\hline
\end{tabular}

The selected sample covered 10 industry segments. The largest industry representation of $19 \%$ is from the Garment sector and the second largest of $13 \%$ is held equally by Conglomerate, Banking and Manufacturing sectors. Food \& Beverage and Transporatation holds $10 \%$ each from the total sample. The smallest portion of $3 \%$ is from Plantation sector. Therefore, it is quite evident that the selected sample is a fair representation of Sri Lankan industries.

There were 45 responses from consultants, but only 32 responses were considered for the analysis since 13 responses were incomplete. Out of 32 responses, $34 \%$ is from MS Dynamics consultants and $31 \%$ is from Oracle consultants. IFS consultants have contributed to this research as one fourth from the total sample size. SAP consultants represent only $10 \%$ of the sample. Possible reason for this might be that only couple of SAP consultancy companies operating in Sri Lanka. Most of the clients hire consultants for SAP implementations from foreign countries such as India and Singapore. Those consultants stay with the client only during the implementation. Therefore it was quite difficult to get their responses for the research.

Table 3.3: ERP Package Representation by Vendor

\begin{tabular}{|l|l|l|l|}
\hline No. & ERP product & $\begin{array}{l}\text { No. of } \\
\text { responses }\end{array}$ & Percentage \\
\hline 1 & SAP & 3 & $10 \%$ \\
\hline 2 & Oracle & 10 & $31 \%$ \\
\hline 3 & IFS & 8 & $25 \%$ \\
\hline 4 & MS Dynamics & 11 & $34 \%$ \\
\hline & & $\mathbf{3 2}$ & $\mathbf{1 0 0 \%}$ \\
\hline
\end{tabular}

Table 3.4 shows the research findings for the client and consultant responses. Also it describes the perception of clients and consultants on application of various factors. One sample t-test was used to test the hypotheses. 
Table 3.4: Overview of the Analysis (At 95\% Confidence Level)

\begin{tabular}{|c|c|c|c|}
\hline No & Factor & Client perspective & Consultant perspective \\
\hline 1 & $\begin{array}{l}\text { Product } \\
\text { procedure. }\end{array}$ & $\begin{array}{l}\text { Reject } \mathrm{H}_{0} \\
\text { i.e. Product selection procedure } \\
\text { is good. }\end{array}$ & $\begin{array}{l}\text { Accept } H_{0} \\
\text { i.e. Product selection } \\
\text { procedure is poor. }\end{array}$ \\
\hline 2 & $\begin{array}{l}\text { Business needs for an ERP } \\
\text { system. }\end{array}$ & $\begin{array}{l}\text { Reject } \mathrm{H}_{0} \\
\text { i.e. Business needs for an ERP } \\
\text { system are correctly understood. }\end{array}$ & $\begin{array}{l}\text { Reject } \mathrm{H}_{0} \\
\text { i.e. Business needs for an ERP } \\
\text { system are correctly } \\
\text { understood. }\end{array}$ \\
\hline 3 & Project Planning. & $\begin{array}{l}\text { Accept } H_{o} \\
\text { i.e. Project planning is poor. }\end{array}$ & $\begin{array}{l}\text { Reject } \mathrm{H}_{0} \\
\text { i.e. Project planning is good. }\end{array}$ \\
\hline 4 & Client commitment. & $\begin{array}{l}\text { Reject } \mathrm{H}_{0} \\
\text { i.e. Client commitment is good. }\end{array}$ & $\begin{array}{l}\text { Accept } H_{0} \\
\text { i.e. Client commitment is } \\
\text { poor. }\end{array}$ \\
\hline 5 & $\begin{array}{l}\text { Competency } \\
\text { consultants. }\end{array}$ & $\begin{array}{l}\text { Accept } \mathrm{H}_{0} \\
\text { i.e. Competency of consultants } \\
\text { is poor. }\end{array}$ & Not Applicable \\
\hline 6 & $\begin{array}{l}\text { Commitment from the top } \\
\text { management. }\end{array}$ & $\begin{array}{l}\text { Reject } \mathrm{H}_{0} \\
\text { i.e. Commitment from top } \\
\text { management is good. }\end{array}$ & $\begin{array}{l}\text { Reject } \mathrm{H}_{0} \\
\text { i.e. Commitment from top } \\
\text { management is good. }\end{array}$ \\
\hline 7 & $\begin{array}{l}\text { Importance given to IT } \\
\text { function within } \\
\text { organization. }\end{array}$ & $\begin{array}{l}\text { Reject } \mathrm{H}_{0} \\
\text { i.e. IT function is considered to be } \\
\text { important within organizations. }\end{array}$ & $\begin{array}{l}\text { Reject } \mathrm{H}_{0} \\
\text { i.e. IT function is considered to } \\
\text { be important within } \\
\text { organizations. }\end{array}$ \\
\hline 8 & $\begin{array}{l}\text { Communication of support } \\
\text { requirements during the } \\
\text { pre-implementation stage. }\end{array}$ & $\begin{array}{l}\text { Accept } \mathrm{H}_{0} \\
\text { i.e. Communication of support } \\
\text { requirements during the pre- } \\
\text { implementation stage is poor. }\end{array}$ & $\begin{array}{l}\text { Accept } \mathrm{H}_{0} \\
\text { i.e. Communication of } \\
\text { support requirements } \\
\text { during the pre- } \\
\text { implementation stage is } \\
\text { poor. }\end{array}$ \\
\hline 9 & $\begin{array}{l}\text { Transfer of system } \\
\text { knowledge to the client. }\end{array}$ & $\begin{array}{l}\text { Reject } \mathrm{H}_{0} \\
\text { i.e. Transfer of system knowledge } \\
\text { to the client is good. }\end{array}$ & $\begin{array}{l}\text { Reject } \mathrm{H}_{0} \\
\text { i.e. Transfer of system } \\
\text { knowledge to the client is good. }\end{array}$ \\
\hline
\end{tabular}

The above analysis reveals that there are 3 poorly rated factors by clients; i.e. project planning, competency of consultants and communication of support requirements during the pre-implementation stage. On the other hand the consultants have rated that product selection procedure, client commitment and communication of support requirements during the preimplementation stage as poor.

\section{Discussion}

This section discusses client and consultant perspectives of ERP implementation factors. In addition, it presents the possible causes for the factors for poor level of practice and suggests guidelines to improve the same.

\section{Client and Consultant Perspectives}

Factor 1: Product Selection Procedure

The clients think that the product selection procedure is good. However, according to the consultants, product selection procedure which clients have been using is poor and not in proper order. They clearly showed that clients who seek ERP systems do not know how to evaluate ERP products available in the market properly. Though clients thought that they were using the correct criteria to evaluate and select an ERP package, consultants see many issues in their selection process. Root causes for this problem may be that the client's lack of knowledge on features of ERP packages, methods of evaluation, scope of the project 
and many more. The studies carried out by Somers and Nelson (2001) and Wong et al. (2005) have also revealed that product selection procedure was poor in their contexts as well. The issue is some clients start to learn about ERP concept only when they start to seek ERP systems for their organizations. In this scenario it seems that consultants are right as they have involved in a number of ERP implementations and they have an overall idea. Therefore, product selection process will be a learning exercise for most of the clients and they learn through mistakes as it's a new topic for them. This might be the reason for the poor rating given by the consultants. According to Upadhyay et al. (2011), proper package selection has been identified as one of the crucial factors after the study carried out among 98 Micro, Small and Medium-scale Enterprises in India. Therefore, companies should be more careful in selecting the most suitable ERP package for their business. Consequences of selecting an inappropriate package will be disastrous.

Factor 2: Business Needs for an ERP System

Both clients and consultants agree that clients understand and justify the need of the ERP well.

\section{Factor 3: Project Planning}

According to the clients, project planning is poor in Sri Lankan ERP implementations. Due to poor project planning, deadlines might be dragged, project plans might be changed frequently and as a result milestones might have not been achieved on time, clients may have confronted budget and time over runs, waste of human resource, etc. Upadhyay et al. (2011) show the criticality of project planning and management in ERP implementations in Indian context. Further they discuss the consequences the stakeholders may face as a result of improper project planning and execution. Huang et al. (2004) also list the lack of effective project management methodologies among top ten risk factors in their study in the Chinese context. It shows that ERP project planning and execution is poor in the Chinese implementations as well.

Even though the clients perceive project planning factor is poor, it is vice versa in the case of consultants, i.e. consultants say that many ERP implementations progressed smoothly as they planned without any delays in achieving milestones and within the budget. But clients say exactly the opposite. The possible reason for this may be client responses were based on the experience of one implementation which one has experienced in his or her company. But vendor/consultant responses were based on their all implementations, in other words general perception of their whole career. Therefore, based on this situation it's impossible to arrive with conclusions on this contradicting view. Nevertheless, Wong et al. (2005) show that project planning is not satisfactory according to their study as well.

\section{Factor 4: Client Commitment}

Wong et al. (2005), Somers and Nelson (2001) and Rao (2000) emphasise the importance of the commitment from the client towards the project success. According to the clients their commitment to the ERP implementation is good in Sri Lankan context. Results of the analysis show that clients are dedicated and supportive to the maximum level during the implementation. They might have submitted key project documents such as master data, trial balances, etc on time, given signoffs without any delays, released payments on time and held project review meetings frequently and attended on time in achieving project success. However, according to consultants, client commitment is poor in Sri Lankan ERP implementations.

Factor 5: Competency of Consultants

The analysis of the responses reveals that clients are not happy about the competency of consultants in ERP vendor companies. In other words competency of consultants is poor in Sri Lanka. Findings of Wong et al. (2005) is in line with this research with respect to competency of 
consultant's factor i.e. clients have pointed out lack of competencies of the consultants. Consultants might lack the product knowledge and at the same time they might have equipped with less domain knowledge such as lack of knowledge in business processes in a particular industry. There may be consultants who have less knowledge in Business Process Reengineering (BPR) in order to streamline existing process by eliminating non value adding activities. Clients might have experienced situations where consultant was not been able to answer product related functional questions thrown by the client to accommodate particular client requirement. There might be a shortage of knowledgeable consultants in the industry. The rigorous literature review carried out by Upadhyay et al. (2011), identified the importance of the competency of consultants for a successful ERP implementation. Therefore a genuine ERP consultant should have functional and technical knowledge as well as domain knowledge.

If the research outcomes are carefully analyzed, one could observe the fact that clients are putting the fault on consultants and at the same time consultants are blaming the clients. Clients complain that there is a problem with the competency of consultants while consultants are pointing finger on the client commitment for the project activities. Nevertheless blaming each other would not bring any solution to the problem; instead consultants should build up their competency and the clients should be more committed and focused to the project activities in order to achieve the project success.

Factor 6: Commitment from the Top Management

Many literature revealed the (Huang and Palvia, 2001; Huang et al., 2004; Upadhyay et al., 2011) importance of top management support and commitment for successful ERP implementation. The analysis shows that both the clients and the consultants agree that the commitment from top management is good in Sri Lankan ERP implementations.
Factor 7: Importance Given to IT Function within the Organization

According to both the clients and the consultants, importance of the IT function within the organization is high according to analysis outcomes. This may be due to the commitment of the top management.

Factor 8: Communication of Support Requirements during the PreImplementation Stage

Both the parties agree that communication of support requirements during the preimplementation stage is poor in Sri Lankan ERP implementations. Currently most of the clients tend to discuss the support requirements after the implementation. If clients have not discussed and agreed upon support and maintenance clauses/requirements of the ERP package during pre-implementation stage, they may confront various issues in postimplementation stage. Few of them are as follows:

- Client might have to pay unexpected high fee for support and maintenance and then it would result in cash flow problems.

- Vendor might not be in a position to provide support and maintenance due to resource issues; hence client might not be able to obtain local support and instead go for foreign support with a higher cost and risk.

- There might not have any vendor to support in a major problem such as system down situation, in turn it would distract business activities and subsequently affect company profits.

Root cause for above issues is that the client has not been equipped with relevant knowledge in order to request support levels from the vendor during the preimplementation stage. Nevertheless, this shows the importance of communication of support issues during pre-implantation stage. 
Consultants may enjoy few advantages over this situation such as over charge of the client for handling support issues and thereby earn short term instant profits. If vendors have not properly discussed and agreed upon the support and maintenance clauses/requirements during preimplementation stage, they may confront various issues in post-implementation stage. Few of them are as follows;

- Client may request to perform support functions free of charge and thereby loss revenue.

- If over charged the client for handling support queries, vendor may loss the client account in terms of support and maintenance.

- After performing a good work during implementation, due to couple of issues on support and maintenance topic, vendor's industry reputation may be damaged.

Factor 9: Transfer of System Knowledge to the Client

Both clients and consultants agree that transfer of system knowledge to the client is good in Sri Lankan implementations, which shows the excellence on training sessions that have been carried out to educate the end user. Upadhyay et al. (2011) and Huang et al. (2004) explain the importance of the system knowledge transfer to the client before leaving the client site in Indian and Chinese contexts respectively. Also use of effective and constructive training methodologies is very important in knowledge transferring. Moreover, training guides and system documents should be properly managed in order to use when a new user starts to use the system.

In overall, both clients and consultants agree that business needs for an ERP system is correctly understood, commitment from top management is good, IT function is considered to be important within organizations and transfer of system knowledge to the client is good in Sri Lankan ERP implementations. Therefore this is a positive sign as far as Sri Lankan ERP implementations are concerned.

\section{Implications to the Industry}

This section discusses set of guidelines to improve effectiveness of factors that were rated either by consultants or clients. In addition to the research findings, discussions held with consultants of three vendor companies and employees of few client organizations in the industry who are in the post-implementation stage were also used in proposing the following guidelines.

\section{Guidelines to Improve Product Selection Procedure:}

It is very important to carry on the product selection procedure giving more emphasis to vendor competency, reference site visits and detailed ERP product demos exhibiting the requirements. In order to verify the competency of vendor consultants, ask for their CVs and assess their qualifications and previous ERP implementation experiences thoroughly, and verify the qualifications via reference site contacts. Assess the stability and the reliability of the vendor company and if the project risk is high, ask for a bank guarantee. If required, obtain support from a third party (unbiased) evaluator/consultant in order to evaluate and select the appropriate ERP package. Moreover, client could request detailed product demonstrations which are specific to their business processes and master data. Since this requires time and efforts from vendor in order to prepare those types of demos, client and vendor can agree on a price for that effort as a separate assignment. This cost is worthwhile to incur by the client, because that will avoid bigger loses later in the implementation. This in turn would help client to understand the fit between the existing business processes and system functionalities. Further, client should not blindly purchase the ERP package that its competitor has invested on. 


\section{Guidelines to Improve Project Planning:}

When planning, client should keep provision in terms of time and resources for day-to-day business activities as well. Client should take in to consideration the month ends and year ends when deciding on key milestones of the project.

Plan everything thoroughly. Subdivide yearly plans to monthly and those in turn in to weekly, daily and if needed in to hourly plans even. For example in data migration, hourly plans are needed when there are time critical data items. Also, when making project estimations and project plans it is essential to get expert advice if the client lack experience in that area (Project planning and estimation). Otherwise it would lead to lot of issues. There should be contingency plans for hardware and software delivery, should look at client staff availability and many more. If client has less staff for day-to-day activities, recruit staff for daily tasks so that the project team members can focus on the project activities effectively.

\section{Guidelines to Improve Client Commitment:}

Internally the organization should get prepared and committed for the implementation. There should be a separate project team from the client organization for the implementation of the project which consists of key users of all business and functional areas of the organization. Then the cross functional project team members can focus and commit for the project activities. Some client organizations use to locate the project team in a different place (locate the project office out of the office premises) so that they could entirely focus on project activities. It is very important that the client organization not to appoint staff members for the project team who do not have thorough knowledge of their business/functional area. On the other hand, the project manager of the team should have the necessary authority to directly communicate directly with the CEO in order to take quick decisions without having to climb the hierarchy. This will ensure that the project will get necessary resources immediately and will help to accelerate the project.

It is important to communicate the need for the ERP system and the corresponding benefits to all employees (from senior managers to lower level employees) of the organization. Commence the project with a "kick off work shop", which is essential to educate the employees about the changes that are going to take place in their organization during coming months. That will help the employees of the client organizations get to know the vendor project team members. This kind of a workshop would boost the commitment of the client project team members and build a cordial relationship between clients and the consultants.

In addition top management should motivate the people to provide the key project documents, sign offs on time, managing office work and project work efficiently by giving rewards or reinforcing the benefits. With related to the above point, many client organizations make the project as a KPI (Key Performance Indicator) of the project manager and team members and reward them accordingly.

Further, frequent communication campaigns should be carried out throughout the project implementation as well. This education would help to motivate the managers and staff members to actively participate and support the implementation. Thereby client's commitment could be increased.

\section{Guidelines to Improve Competency of Consultants:}

Consultants should posses both functional and domain knowledge in order to carry out their tasks comfortably in the client site. Therefore consultants must be certified in the relevant modules that they are capable of implementing. Also there are different methodologies of implementing different ERP packages. For example, Oracle has introduced its latest implementation methodology namely OBA (Oracle Business Accelerators). It is an 
automated tool which helps to configure the system automatically based on the input parameters of the consultant. Since OBA tool takes care of configuration part, it will minimize consultant mistakes and implementation duration.

Client should evaluate the relevant implementation experience of each consultant of the vendor project team during the product selection stage. Vendor should not include fresh consultants with no implementation experience directly to the implementation before proper training or engage in support issues. Client can request full CVs of the consultants in order to evaluate the industry background of each.

Guidelines to Improve Communication of Support Requirements during the PreImplementation Stage:

Vendor should educate the client about support and maintenance phase and relevant charges during preimplementation stage itself. For example, if the support issues are handled over the phone or via e-mail what is the price or else if the support is provided by visiting the client then what would be the price, all that should be clearly communicated to the client. It will also help to set the correct expectations in clients with respect to project support. Moreover, the project contract must contain a clause on the first year technical and functional support that should be received from the vendor. And the vendor should insist on including such a clause for the betterment of the project plus discuss in detail regarding the support requirements before the contract is agreed on. When deciding on the period of support on which the vendors will be in the client site while the system is functioning as the live system, take in to account practical considerations such as computer literacy of the employees of the organization and their adoption rates.

\section{Conclusion}

Among the nine factors identified through literature and domain expert's views, there are 3 factors each for client and consultant perspectives that they have identified as poor. They are product selection procedure, project planning, client commitment, (by consultants) competency of consultants (by clients) and communication of support requirements during the pre-implementation stage (by both parties). Except for above, level of practice of rest of the factors is good according to both clients and consultants. Therefore this is a positive sign as far as Sri Lankan ERP implementations are concerned.

Further research may focus on finding out level of practice of identified factors with respect to different industries as well as different ERP products. In addition to that a study can be carried out to compare product features and find out product specific issues in terms of functional and technical features. Moreover, it would be more useful for the stakeholders if one could rank factors according to the significance of each factor use of AHP analysis.

In this research, attention was paid only for micro factors (organizational factors). But the literature shows that macro factors (regional, government, economy and economic growth, etc) also have an impact on ERP implementations.

This research was done using questionnaires, in other words research has used deductive approach. It is possible to extend this research by conducting indepth interviews for both clients and consultants as an exploratory study.

\section{References}

Al-Mashari, M. (2003). "Enterprise Resource Planning (ERP) Systems: A Research Agenda," Industrial Management and Data Systems, 103 (1), 7-22.

AMR Research. (2007). The ERP Market Sizing Report, 2006-2011, AMR Research Inc, Boston.

Bingi, P., Sharma, M. K. \& Godla, J. K. (1999). "Critical Issues Affecting an ERP 
Implementation," Information Systems Management, 16 (3), 7-14.

Davenport, T. H. (1998). "Putting the Enterprise into the Enterprise System," Harvard Business Review, July-August, 31121.

Ehie, I. C. \& Madsen, M. (2005). "Identifying Critical Issues in Enterprise Resource Planning (ERP) Implementation," Computers in Industry, 56, 545-557.

Gunasekaran, A. (2007). Modeling and Analysis of Enterprise Information Systems, IGI Publishing, USA.

Hellens, L., Nielsen, S. \& Beekhuyzen, J. (2005). Qualitative Case Studies in Implementing Enterprise Wide Systems, IGI Publishing, USA.

Huang, S. M., Chang, I. C., Li, S. H. \& Lin, M. T. (2004). "Assessing Risk in ERP Projects: Identify and Prioritize the Factors," Industrial Management \& Data Systems, 104 (8), 681-688.

Huang, Z. \& Palvia, P. (2001). "ERP Implementation Issues in Advanced and Developing Countries," Business Process Management Journal, 7 (3), 276-284.

Kim, Y., Lee, Z. \& Gosain, S. (2005). "Impediments to Successful ERP Implementation Process," Business Process Management Journal, 11 (2), 158-170.

Light, B., Holland, C. P. \& Wills, K. (2001). "ERP and Best of Breed: A Comparative Analysis," Business Process Management Journal, 7 (3), 216-224.

Nah, F. F.- H., Lau, J. L.- S. \& Kuang, J. (2001). "Critical Factors for Successful Implementation of Enterprise Systems," Business Process Management Journal, 7 (3), 285-296.

Rao, S. S. (2000). "Enterprise Resource Planning: Business Needs and Technologies," Industrial Management \& Data Systems, 1000 (2), 105-116.

Scott, J. E. \& Vessey, I. (2002). "Managing Risks in Enterprise Systems
Implementations," Communication of the ACM, 45 (4), 74-81.

Somers, T. M. \& Nelson, K. (2001). "The Impact of Critical Success Factors Across the Stages of Enterprise Resource Planning Implementations," Proceedings of the 34th Hawaii International Conference on System Sciences (HICSS), Maui, Hawaii, 2001.

Upadhyay, P., Jahanyan, S. \& Dan, P. (2011). "Factors Influencing ERP Implementation in Indian Manufacturing Organizations," Journal of Enterprise Information Management, 24 (2), 130-145.

Williamson, M. (1997). 'From SAP to Nuts!,' Computerworld, 31 (45), 68-69.

Willis, T. H. \& Willis-Brown, A. H. (2002). "Extended the Value of ERP," Industrial Management \& Data Systems, 102 (1), 8-35.

Wong, A., Scarbrough, H., Chau, P. Y. K. \& Davison, R. (2005). "Critical Failure Factors in ERP Implementation," Proceedings of the Ninth Pacific Asia Conference on Information Systems (PACIS), Bangkok, Thailand, 2005.

Yu, C. S. (2005). "Causes Influencing the Effectiveness of the Post-Implementation ERP System," Industrial Management \& Data Systems, 105 (1), 115-132. 